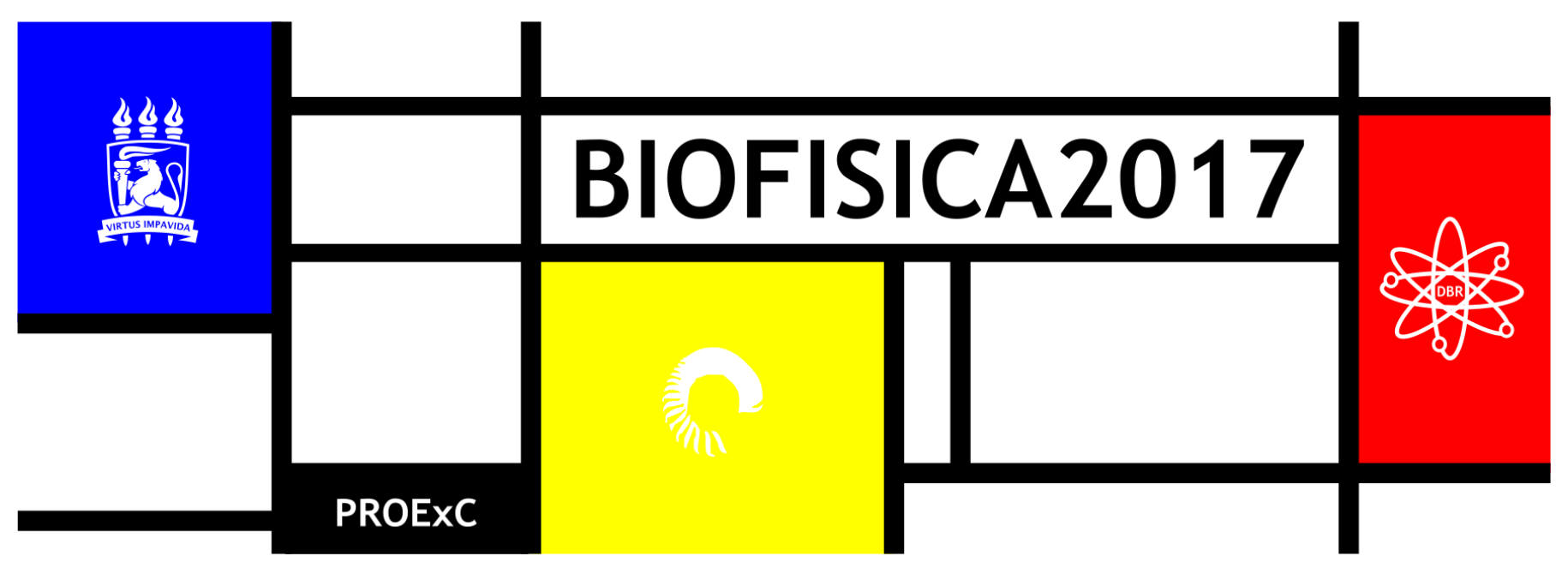

\title{
NANOCÁPSULAS PEPTÍDICAS COMO UMA POSSÍVEL ALTERNATIVA PARA A VEICULAÇÃO DE COMPOSTOS TERAPÊUTICOS
}

\author{
Sheila de M. Barros ${ }^{1,2, *}$, Susan K. Whitaker ${ }^{1}$, Pinakin Sukthankar ${ }^{3}$, Eduardo I. C. Beltrão ${ }^{2}$, John M. Tomich
}

${ }^{1}$ Departamento de Bioquímica e Biofísica Molecular, Kansas State University, Manhattan, KS, U.S.A.; ${ }^{2}$ Departamento de Bioquímica e Fisiologia, Universidade Federal de Pernambuco -UFPE, Recife, Pernambuco, Brasil.; ${ }^{3}$ Departamento Biociências , University of Kansas, Lawrence KS, U.S.A. * bioquimsheila@gmail.com

Um dos maiores desafios da pesquisa farmacêutica tem sido o desenvolvimento de nanocarreadores capazes de promover a entrega de compostos farmacológicos, em dosagens apropriadas, para células ou tecidos alvo de uma maneira segura e reproduzível. Nessa perspectiva, sistemas de entrega de fármacos a base de peptídeos têm demonstrado um grande potencial na veiculação segura de drogas. Cápsulas peptídicas anfifílicas ramificadas ou do inglês, "Branched Amphiphilic Peptide Capsules" (BAPCs), são nanocápsulas formadas pela organização de dois peptídeos de diferentes tamanhos (AC-FLIVI)2-K-K4-CO-NH2 e (AC-FLIVIGSII)2-K$\mathrm{K} 4-\mathrm{CO}-\mathrm{NH} 2$. As BAPCs são estruturas que se auto-organizam de modo a formar uma cavidade aquosa envolvida por uma bicamada constituída por peptídeos anfifílicos, mimetizando o comportamento e arquitetura molecular de fosfoglicerídeos. São, no entanto, mais estáveis que vesículas lipídicas, resistindo ao rompimento na presença de caotrópicos tais como guanidina e ureia, proteases e elevadas temperaturas. São facilmente incorporados a células em cultura e têm demonstrando ser resistentes à degradação por parte do sistema retículo endotelial (SER), além de apresentar uma ampla possibilidade de modificação estrutural. Estudos de caracterização recentes, têm demonstrado que as sequências peptídicas FLIVI e FLIVIGSII podem dar origem a cápsulas de tamanhos que variam de 20 a $150 \mathrm{~nm}$ de diâmetro de acordo com as condições de preparação e proporções dos peptídeos utilizados na sua confecção, abrindo a possibilidade do uso das nanocápsulas peptídicas para o encapsulamento de moléculas de tamanhos variados. Além disso, as BAPCs podem ser facilmente funcionalizadas com o uso de ligantes de superfície de modo a atingir alvos específicos, fato que as torna fortes candidatas para a entrega de compostos destinados ao tratamento de câncer. Estudos de transfecção demonstraram ainda, que tais sequências formam complexos com os plasmídeos de DNA, condensando-os em estruturas compactas, mantendo as características de estabilidade e especificidade até então observadas nas nanocápsulas, sugerindo que os peptídeos anfifílicos ramificados podem ser utilizados tanto para a entrega de compostos farmacólogos quanto nos estudos de terapia gênica. 